\title{
ANALISIS FAKTOR-FAKTOR YANG BERHUBUNGAN DENGAN KEJADIAN ANEMIA GIZI BESI PADA REMAJA PUTRI DI SMKN 1 TERBANGGI BESAR LAMPUNG TENGAH
}

\author{
Akma Listiana \\ Akademi Kebidanan Panca Bhakti Bandar Lampung \\ Email: akmalistiana@gmail.com
}

\begin{abstract}
Analysis Factors that Related to the Incidence of Iron Defeciency Anemia of Teenage Girls in SMKN 1 Terbanggi Besar, Central Lampung. The prevalence of anemia at teenage girls according to the Ministry of Health, Republic of Indonesia (2007) is still quite high, which is still at $28 \%$ from total and this number is classified as a public health problem because the prevalence is $\geq 40 \%$. The data of the presurvey from 100 teenage girls in SMKN 1 Terbanggi Besar in September 2011 showed that 30 (30\%) of them was experiencing the symptoms of anemia. This study was to determine the factors related to the anemia in teenage girls in SMKN 1 Terbanggi Besar, Central Lampung, in 2012 which includes family income, maternal education, tea-drinking habits, body mass index, knowledge, attitudes, incidence of infection, the state of menstruation, and intake of iron supplements. This study was quantitative research with a cross sectional approach, conducted in February 2012, the whole population were 600 young women while as many as 255 samples were taken, the sampling technique was a random sampling method and the data collection tool was using a questionnaire technique. Datas analyzed by univariate, bivariate using the chi-square, and multivariate using logistic regression prediction model. The results showed that a total of 155 teenage girls was experiencing the symptoms of anemia $(60,8 \%)$ and from the nine variables examined, the results obtained were: family income (p-value 0,004 ad $\mathrm{OR}=2,442$ ), maternal education ( $\mathrm{p}$-value 0,002 and $\mathrm{OR}=2,349$ ), tea-drinking habits ( $\mathrm{p}$-value 0,002 and $\mathrm{OR}=2,554$ ), body mass index ( $\mathrm{p}$-value 0,011 and $\mathrm{OR}=2,047$ ), the state of menstruation ( $\mathrm{p}$ value 0,004 and $O R=2,349$ ), and intake of iron supplements ( $\mathrm{p}$-value 0,005 and $\mathrm{OR}=2,344$ ).
\end{abstract}

Keywords: Iron deficiency anemia, Influencing factors, Teenage girls

\begin{abstract}
Abstrak: Analisis Faktor-faktor yang Berhubungan dengan Kejadian Anemia Gizi Besi pada Remaja Putri di SMK Negeri 1 Terbanggi Besar Lampung Tengah. Prevalensi anemia pada remaja putri menurut Depkes RI (2007) masih cukup tinggi yaitu sebesar 28\%, angka ini tergolong masalah kesehatan masyarakat karena prevalensinya $\_40 \%$. Data pra survei terhadap 100 remaja putri di SMKN 1 Terbanggi Besar pada bulan September 2011 diketahui sebanyak 30 (30\%) remaja putri mengalami gejala anemia. Tujuan dalam penelitian ini adalah untuk mengetahui Faktor-faktor yang Berhubungan dengan Kejadian Anemia pada Remaja Putri di SMKN 1 Terbanggi Besar Kabupaten Lampung Tengah Tahun 2012 yang meliputi pendapatan keluarga, pendidikan ibu, kebiasaan minum teh, indeks massa tubuh, pengetahuan, sikap, kejadian infeksi, keadaan menstruasi, asupan suplemen zat besi. Penelitian ini adalah penelitian kuantitatif dengan pendekatan cross sectional, dilakukan pada bulan februari 2012, jumlah populasi seluruhnya adalah 600 remaja putri sedangkan sampel yang diambil sebanyak 255, tekhnik sampling yaitu randome sampling dan alat pengumpulan data adalah dengan tekhnik angket. Analisis data yang digunakan adalah univariat, bivariat dengan uji statistik menggunakan chi square, dan multivariat dengan regresi logisatic model prediksi. Hasil penelitian menyimpulkan dari 255 responden, yang anemia sebanyak 155 remaja putri $(60,8 \%)$, dan dari 9 variabel yang diteliti didapatkan hasil: pendapatan keluarga ( $p$-value 0,004 dan $O R=2,442$, pendidikan ibu ( $p$-value 0,002 dan $O R=2,349$ ), kebiasaan minum teh ( $p$-value 0,002 dan $O R=2,554)$, indeks massa tubuh ( $p$-value 0,002 dan $O R=2,329$ ), pengetahuan ( $p$-value 0,002 dan $O R=2,298$ ), sikap ( $p$-value 0,011 dan $O R=2,047$ ), keadaan menstruasi ( $p$-value 0,004 dan $O R=2,349$ ) dan asupan suplemen zat besi ( $p$-value 0,005 dan $O R=2,344)$. Peneliti menyarankan bagi petugas kesehatan agar terus meningkatkan penyuluhan dan konseling serta bimbingan bagi remaja putri untuk dapat mencegah anemia.
\end{abstract}

Kata kunci: Anemia gizi besi, Faktor yang mempengaruhi, Remaja putri

Salah satu indikator status gizi masyarakat adalah prevalensi anemia gizi besi. Anemia gizi besi merupakan masalah gizi mikro terbesar di dunia terutama bagi kelompok wanita usia subur (WUS). Anemia terjadi pada $45 \%$ wanita di negara berkembang dan $13 \%$ di negara maju. 
Terdapat 12\% WUS di Amerika Serikat berusia 15-49 tahun dan $11 \%$ wanita hamil usia subur mengalami anemia. Di beberapa negara, prevalensi anemia defesiensi besi pada remaja putri yaitu: $82,5 \%$ di Bangladesh, $23 \%$ di China, $42,2 \%$ di Filipina, dan $74,7 \%$ di India (Demaeyer, 2003). Berdasarkan analisis yang didukung oleh WHO/Bank Dunia, "Global Burden of Disease," anemia defisiensi besi menduduki peringkat ketiga terbesar sebagai masalah kesehatan berdasarkan DALY (Dissability-Adjusted Life Years) pada wanita usia 15-44 tahun (Departemen Gizi dan Kesehatan Masyarakat, FKUI, 2007).

Anemia gizi besi pada remaja putri merupakan masalah yang umum dijumpai terutama di negara-negara berkembang seperti halnya di Indonesia, prevalensi anemia pada remaja putri menurut Depkes RI (2007) masih cukup tinggi yaitu sebesar 28\%. Data SKRT tahun 2004 juga menyatakan bahwa prevalensi anemia defisiensi besi pada remaja putri cenderung naik dan yang tertinggi $57,1 \%$ dibandingkan kelompok lain pada balita 40,5\%, ibu hamil 50,1\% dan ibu nifas 45,1\%. Hasil RISKESDAS 2007 juga menunjukkan angka kejadian anemia gizi Besi sebesar 19,7\% terjadi pada perempuan dewasa ( $\geq 15$ tahun).

Dampak anemia gizi besi pada remaja adalah menurunnya produktivitas kerja ataupun kemampuan akademis disekolah, karena tidak adanya gairah belajar dan konsentrasi belajar. Anemia gizi besi juga dapat mengganggu pertumbuhan dimana tinggi dan berat badan menjadi tidak sempurna, menurunkan daya tahan tubuh sehingga mudah terserang penyakit. Berdasarkan siklus daur hidup, anemia gizi besi pada saat remaja akan berpengaruh besar pada saat kehamilan dan persalinan, yaitu terjadinya abortus, melahirkan bayi dengan berat badan lahir rendah, mengalami penyulit lahirnya bayi karena rahim tidak mampu berkontraksi dengan baik serta risiko terjadinya perdarahan pasca persalinan yang menyebabkan kematian maternal (Poltekkes Depkes Jakarta I, 2010). Penyebab utama anemia gizi besi pada wanita adalah kurang memadainya asupan makanan sumber $F e$, perdarahan patologis akibat penyakit malaria atau infeksi parasit seperti cacingan, Penyebab lainnya dari anemia defisiensi besi adalah dikarenakan asupan dan serapan zat besi yang tidak adekuat, yaitu dengan kebiasaan mengkonsumsi makanan yang dapat mengganggu penyerapan zat besi seperti teh secara bersamaan pada waktu makan, Faktor lain terjadinya anemia gizi besi pada remaja putri yaitu pengetahuan yang kurang tentang anemia, sikap yang tidak mendukung, pendidikan ibu maupun tingkat sosial ekonomi keluarga.

Berdasarkan hasil presurvey terhadap 100 orang siswi di SMK Negeri 1 Terbanggi Besar Lampung Tengah pada bulan September 2011 diketahui bahwa sebanyak 30 orang siswi ataupun sebesar $30 \%$ siswi yang mengalami gejala anemia gizi besi yaitu lemah, letih, lesu, mudah mengantuk, nafas pendek, pucat dan nafsu makan yang kurang. Dari hasil wawancara terhadap 30 orang siswi yang mengalami gejala tersebut, sebanyak 15 siswi atau $50 \%$ diantaranya sedang mengalami menstruasi, dan sebanyak 20 siswi atau sebesar 66\% mengatakan memiliki kebiasaan selalu minum teh bersamaan pada saat makan serta mengaku belum pernah mendapatkan informasi terkait anemia gizi besi dari guru maupun tenaga kesehatan di puskesmas setempat. Berdasarkan informasi yang didapatkan dari kepala sekolah diketahui pula bahwa kurikulum di SMKN 1 belum ada yang memuat materi terkait anemia gizi besi (AGB). Tujuan dari penelitian ini adalah untuk menganalisis faktor-faktor yang berhubungan dengan anemia gizi besi pada remaja putri di SMK Negeri 1 Terbanggi Besar Lampung Tengah tahun 2012.

\section{METODE PENELITIAN}

Jenis penelitian ini adalah kuantitatif dengan desain survei analitik dan pendekatan cross sectional yaitu pengambilan data dilakukan pada waktu yang bersamaan. Populasi dalam penelitian ini adalah seluruh remaja putri di SMK Negeri 1 Terbanggi Besar Lampung Tengah yang berjumlah 600 remaja putri. Selanjutnya untuk memperkirakan besar sampel, peneliti menggunakan rumus estimasi proporsi pada simple random sampling dengan presisi mutlak (Lemeshow, 1997) dengan rumus sebagai berikut:

$$
\mathrm{n}=\frac{\mathrm{Z}^{2} \times \mathrm{P}(1-\mathrm{P}) \mathrm{N}}{\mathrm{d}^{2}(\mathrm{~N}-1)+\mathrm{Z}^{2} \times \mathrm{P}(1-\mathrm{P})}
$$

Sehingga besar sampel minimal yang digunakan pada penelitian ini sebanyak 232 remaja putri, untuk mengantisipasi kemungkinan adanya drop out maka besar sampel dinaikkan $10 \%$ sehingga jumlah sampel 255 remaja putri di SMKN 1 Terbanggi Besar Kabupaten Lampung Tengah. Dengan kriteria inklusi adalah remaja putri usia 13-18 tahun, remaja putri sudah mengalami haid atau menstruasi dan remaja putri bersedia menjadi responden dalam penelitian. Kriteria Eksklusi yaitu pada saat dilakukan pemeriksaan kadar $H b$ remaja putri sedang 
berpuasa, remaja putri sudah bekerja dan tidak bersedia menjadi responden dalam penelitian. Tehnik pengambilan sampel menggunakan Tehnik Random Sampling. Penelitian ini dilaksanakan pada bulan Februari 2012. Lokasi penelitian ini adalah SMKN 1 Terbanggi Besar Kabupaten Lampung Tengah.

Analisis kuantitatif dilakukan melalui analisis univariat untuk melihat distribusi masing-masing variabel, analisis bivariat menggunakan Chi Square. Analisis multivariat menggunakan regresi logistik untuk melihat besar pengaruh variabel bebas terhadap variabel terikat.

\section{HASIL}

\section{A. ANALISIS UNIVARIAT}

\section{Distribusi Frekuensi Responden Berdasarkan Kejadian Anemia Defesiensi Zat Besi pada Remaja Putri}

\section{Tabel 1. Distribusi Frekuensi Responden Berdasarkan Kejadian Anemia Defesiensi Zat Besi pada Remaja Putri}

\begin{tabular}{lcr}
\hline \multirow{2}{*}{ Kejadian Anemia } & \multicolumn{2}{c}{ Jumlah } \\
\cline { 2 - 3 } & n & \% \\
\hline Anemia gizi besi & 155 & 60,8 \\
Tidak anemia gizi besi & 100 & 39,2 \\
\hline Total & 255 & 100,0 \\
\hline
\end{tabular}

Berdasarkan hasil penelitian untuk variabel kejadian anemia menunjukkan bahwa sebagian besar responden anemia yaitu $60,8 \%$, variabel pendapatan keluarga menunjukkan bahwa sebagian besar pendapatan keluarga rendah yaitu $76,1 \%$, variabel pendidikan ibu menunjukkan sebagian besar responden pendidikan ibunya rendah yaitu $63,1 \%$, variabel kebiasaan minum teh menunjukkan bahwa sebagian besar responden minum teh yaitu $73,3 \%$, variabel indeks massa tubuh menunjukkan bahwa sebagian besar responden memiliki indeks massa tubuh tidak normal yaitu $63,9 \%$, variabel pengetahuan menunjukkan sebagian besar responden pengetahuan tentang anemia kurang yaitu $62,0 \%$, variabel sikap menunjukkan sebagian besar sikap responden tidak mendukung yaitu $62,4 \%$, variabel kejadian infeksi menunjukkan bahwa sebagian besar responden menderita penyakit infeksi yaitu $65,9 \%$, variabel asupan suplemen zat besi menunjukkan bahwa sebagian besar responden tidak mengkonsumsi yaitu $74,1 \%$, variabel kejadian menstruasi menunjukkan sebagian besar responden menstruasi yaitu $73,3 \%$.

Tabel 2. Distribusi Frekuensi Faktor- faktor yang Mempengaruhi Kejadian Anemia pada Remaja Putri

\begin{tabular}{|c|c|c|}
\hline \multirow{2}{*}{ Variabel } & \multicolumn{2}{|c|}{ Jumlah } \\
\hline & $\mathbf{n}$ & $\%$ \\
\hline \multicolumn{3}{|l|}{ Pendapatan keluarga } \\
\hline Rendah & 194 & 76,1 \\
\hline Tinggi & 61 & 23,9 \\
\hline Total & 255 & 100 \\
\hline \multicolumn{3}{|l|}{ Pendidikan Ibu } \\
\hline Rendah & 161 & 63,1 \\
\hline Tinggi & 94 & 36,9 \\
\hline Total & 255 & 100 \\
\hline \multicolumn{3}{|l|}{ Kebiasaan minum teh } \\
\hline Minum teh & 187 & 73,3 \\
\hline Tidak minum teh & 68 & 26,7 \\
\hline Total & 255 & 100 \\
\hline \multicolumn{3}{|l|}{ Indeks Massa Tubuh } \\
\hline Tidak normal & 163 & 63,9 \\
\hline Normal & 92 & 36,1 \\
\hline Total & 255 & 100 \\
\hline \multicolumn{3}{|l|}{ Pengetahuan } \\
\hline Kurang & 158 & 62,0 \\
\hline Baik & 97 & 58,0 \\
\hline Total & 255 & 100 \\
\hline \multicolumn{3}{|l|}{ Sikap } \\
\hline Tidak Mendukung & 159 & 62,4 \\
\hline Mendukung & 96 & 37,6 \\
\hline Total & 255 & 100 \\
\hline \multicolumn{3}{|l|}{ Kejadian Infeksi } \\
\hline $\begin{array}{l}\text { Menderita } \quad \text { Penyakit } \\
\text { Infeksi }\end{array}$ & 168 & 65,9 \\
\hline $\begin{array}{l}\text { Tidak Menderita Penyakit } \\
\text { Infeksi }\end{array}$ & 87 & 34,1 \\
\hline Total & 255 & 100 \\
\hline \multicolumn{3}{|l|}{ Asupan Suplemen Zat Besi } \\
\hline Tidak Mengkonsumsi & 189 & 74,1 \\
\hline Mengkonsumsi & 66 & 25,9 \\
\hline Total & 255 & 100 \\
\hline \multicolumn{3}{|l|}{ Keadaan Menstruasi } \\
\hline Tidak Menstruasi & 187 & 73,3 \\
\hline Menstruasi & 68 & 26,7 \\
\hline Total & 255 & 100 \\
\hline
\end{tabular}




\section{B. ANALISIS BIVARIAT}

\section{Kejadian Anemia Defesiensi Zat Besi pada Remaja Putri}

Tabel 3. Hubungan Pendapatan Keluarga dengan Kejadian Anemia Defesiensi Zat Besi pada Remaja Putri

\begin{tabular}{|c|c|c|c|c|c|c|c|c|}
\hline \multirow[t]{3}{*}{ Pendapatan Keluarga } & \multicolumn{4}{|c|}{ Kejadian Anemia } & \multirow{2}{*}{\multicolumn{2}{|c|}{ Total }} & \multirow{3}{*}{ p-value } & \multirow{3}{*}{$\begin{array}{c}\text { OR } \\
(95 \% \text { CI })\end{array}$} \\
\hline & \multicolumn{2}{|c|}{ Anemia } & \multicolumn{2}{|c|}{ Tidak anemia } & & & & \\
\hline & $\mathbf{n}$ & $\%$ & $\mathbf{n}$ & $\%$ & $\mathbf{n}$ & $\%$ & & \\
\hline Rendah & 128 & 66,0 & 66 & 34,0 & 194 & 100 & \multirow{3}{*}{0,004} & \multirow{3}{*}{2,442} \\
\hline Tinggi & 27 & 44,3 & 34 & 55,7 & 61 & 100 & & \\
\hline Total & 155 & 60,8 & 100 & 39,2 & 255 & 100 & & \\
\hline
\end{tabular}

Hasil uji statistik pada tabel 3 diperoleh artinya remaja putri yang pendapatan keluarga nilai $p$-value 0,004 , disimpulkan secara statistik rendah mempunyai resiko 2,442 kali untuk ada hubungan yang signifikan antara pendapatan terkena anemia dibandingkan dengan remaja keluarga dengan kejadian anemia. Berdasarkan putri yang pendapatan keluarganya tinggi. hasil analisis diperoleh pula nilai $O R=2,442$,

\section{Hubungan antara Pendidikan Ibu dengan Kejadian Anemia Defesiensi Zat Besi pada} Remaja Putri

Tabel 4. Hubungan antara Pendidikan Ibu dengan Kejadian Anemia Defesiensi Zat Besi pada Remaja Putri

\begin{tabular}{|c|c|c|c|c|c|c|c|c|}
\hline \multirow{3}{*}{ Pendidikan Ibu } & \multicolumn{4}{|c|}{ Kejadian Anemia } & \multirow{2}{*}{\multicolumn{2}{|c|}{ Total }} & \multirow{3}{*}{ p-value } & \multirow{3}{*}{$\begin{array}{c}\text { OR } \\
(95 \% C I)\end{array}$} \\
\hline & \multicolumn{2}{|c|}{ Anemia } & \multicolumn{2}{|c|}{ Tidak Anemia } & & & & \\
\hline & n & $\%$ & $\mathbf{n}$ & $\%$ & $\mathbf{n}$ & $\%$ & & \\
\hline Rendah & 110 & 68,3 & 51 & 31,7 & 161 & 100 & \multirow{3}{*}{0,002} & \multirow{3}{*}{$\begin{array}{c}2,349 \\
(1,391-3,964)\end{array}$} \\
\hline Tinggi & 45 & 47,9 & 49 & 52,1 & 94 & 100 & & \\
\hline Total & 155 & 60,8 & 100 & 39,2 & 255 & 100 & & \\
\hline
\end{tabular}

Hasil uji statistik sesuai Tabel 4 diperoleh nilai $p$-value 0,002 , disimpulkan secara statistik ada hubungan yang bermakna antara pendidikan ibu dengan kejadian anemia pada remaja putri di SMK Negeri 1 Terbanggi Besar Kabupaten Lampung Tengah Tahun 2012. Berdasarkan hasil analisis diperoleh pula nilai $O R=2,349$, artinya remaja putri yang pendidikan ibunya rendah mempunyai risiko 2,349 kali untuk terkena anemia dibandingkan dengan remaja putri yang pendidikan ibunya tinggi.

\section{Hubungan antara Kebiasaan Minum Teh dengan Kejadian Anemia Defesiensi Zat Besi pada Remaja Putri}

Tabel 5. Hubungan antara Kebiasaan minum teh dengan Kejadian Anemia Defesiensi Zat Besi pada Remaja Putri

\begin{tabular}{|c|c|c|c|c|c|c|c|c|}
\hline \multirow{3}{*}{ Kebiasaan Minum Teh } & \multicolumn{4}{|c|}{ Kejadian Anemia } & \multirow{2}{*}{\multicolumn{2}{|c|}{ Total }} & \multirow{3}{*}{ p-value } & \multirow{3}{*}{$\begin{array}{c}\text { OR } \\
(95 \% C I)\end{array}$} \\
\hline & \multicolumn{2}{|c|}{ Anemia } & \multicolumn{2}{|c|}{ Tidak Anemia } & & & & \\
\hline & $\mathbf{n}$ & $\%$ & $\mathbf{n}$ & $\%$ & $\mathbf{n}$ & $\%$ & & \\
\hline Minum Teh & 125 & 66,8 & 62 & 33,2 & 187 & 100 & \multirow{3}{*}{0,002} & \multirow{3}{*}{$\begin{array}{c}2,554 \\
(1,448-4,504)\end{array}$} \\
\hline Tidak Minum Teh & 30 & 44,1 & 38 & 55,9 & 68 & 100 & & \\
\hline Total & 155 & 60,8 & 100 & 39,2 & 255 & 100 & & \\
\hline
\end{tabular}

Pada Tabel 5 hasil uji statistik diperoleh nilai $p$-value 0,002 , disimpulkan secara statistik ada hubungan yang bermakna antara kebiasaan minum teh dengan kejadian anemia pada remaja putri di SMK Negeri 1 Terbanggi Besar Kabupaten Lampung Tengah Tahun 2012.
Berdasarkan hasil analisis diperoleh pula nilai $O R=2,554$ artinya remaja putri yang minum teh mempunyai risiko 2,554 kali untuk terkena anemia dibandingkan dengan remaja putri yang tidak minum teh. 
4. Hubungan antara Indeks Massa Tubuh dengan Kejadian Anemia Defesiensi Zat Besi pada Remaja Putri

Tabel 6. Hubungan antara Indeks Massa Tubuh dengan Kejadian Anemia Defesiensi Zat Besi pada Remaja Putri

\begin{tabular}{|c|c|c|c|c|c|c|c|c|}
\hline \multirow{3}{*}{ Indeks Massa Tubuh } & \multicolumn{4}{|c|}{ Kejadian Anemia } & \multirow{2}{*}{\multicolumn{2}{|c|}{ Total }} & \multirow{3}{*}{ p-value } & \multirow{3}{*}{$\begin{array}{c}O R \\
(95 \% \mathrm{CI})\end{array}$} \\
\hline & \multicolumn{2}{|c|}{ Anemia } & \multicolumn{2}{|c|}{ Tidak Anemia } & & & & \\
\hline & $\mathbf{n}$ & $\%$ & $\mathbf{n}$ & $\%$ & $\mathbf{n}$ & $\%$ & & \\
\hline Tidak Normal & 111 & 68,1 & 52 & 31,9 & 163 & 100 & \multirow{3}{*}{0,002} & \multirow{3}{*}{$\begin{array}{c}2,329 \\
(1,377-3,937)\end{array}$} \\
\hline Normal & 44 & 47,8 & 48 & 52,2 & 92 & 100 & & \\
\hline Total & 155 & 60,8 & 100 & 39,2 & 255 & 100 & & \\
\hline
\end{tabular}

Tabel 6 Hasil uji statistik diperoleh nilai $p$ value 0,002 , disimpulkan secara statistik ada hubungan yang bermakna antara indeks masa tubuh dengan kejadian anemia pada remaja putri di SMK Negeri 1 Terbanggi Besar Kabupaten Lampung Tengah Tahun 2012. Berdasarkan hasil analisis diperoleh pula nilai $O R=2,329$, artinya remaja putri yang indeks massa tubuhnya tidak normal mempunyai risiko 2,329 kali untuk terkena anemia dibandingkan dengan remaja putri yang indeks massa tubuhnya normal.

\section{Hubungan antara Pengetahuan dengan Kejadian Anemia Defesiensi Zat Besi pada Remaja Putri}

Tabel 7. Hubungan antara Pengetahuan dengan Kejadian Anemia Defesiensi Zat Besi pada Remaja Putri

\begin{tabular}{|c|c|c|c|c|c|c|c|c|}
\hline \multirow{3}{*}{ Pengetahuan } & \multicolumn{4}{|c|}{ Kejadian Anemia } & \multirow{2}{*}{\multicolumn{2}{|c|}{ Total }} & \multirow{3}{*}{ p-value } & \multirow{3}{*}{$\begin{array}{c}O R \\
(95 \% C I)\end{array}$} \\
\hline & \multicolumn{2}{|c|}{ Anemia } & \multicolumn{2}{|c|}{ Tidak Anemia } & & & & \\
\hline & $\mathbf{n}$ & $\%$ & n & $\%$ & $\mathbf{n}$ & $\%$ & & \\
\hline Kurang & 108 & 68,4 & 50 & 31,6 & 158 & 100 & \multirow{3}{*}{0,002} & \multirow{3}{*}{$\begin{array}{c}2,298 \\
(1,365-3,867)\end{array}$} \\
\hline Baik & 47 & 48,5 & 50 & 51,5 & 97 & 100 & & \\
\hline Total & 155 & 60,8 & 100 & 39,2 & 255 & 100 & & \\
\hline
\end{tabular}

Hasil uji statistik pada tabel 7 diperoleh nilai $p$-value 0,002 , disimpulkan secara statistik ada hubungan yang bermakna antara pengetahuan dengan kejadian anemia pada remaja putri di SMK Negeri 1 Terbanggi Besar Kabupaten Lampung Tengah Tahun 2012. Berdasarkan hasil analisis diperoleh pula nilai $O R=2,298$, artinya remaja putri yang pengetahuan kurang mempunyai risiko 2,298 kali untuk terkena anemia dibandingkan dengan remaja putri yang pengetahuan baik.

\section{Hubungan antara Sikap dengan Kejadian Anemia Defesiensi Zat Besi pada Remaja Putri}

Tabel 8. Hubungan antara Sikap dengan Kejadian Anemia Defesiensi Zat Besi pada Remaja Putri

\begin{tabular}{|c|c|c|c|c|c|c|c|c|}
\hline \multirow{3}{*}{ Sikap } & \multicolumn{4}{|c|}{ Kejadian Anemia } & \multirow{2}{*}{\multicolumn{2}{|c|}{ Total }} & \multirow{3}{*}{ p-value } & \multirow{3}{*}{$\begin{array}{c}O R \\
(95 \% C I)\end{array}$} \\
\hline & \multicolumn{2}{|c|}{ Anemia } & \multicolumn{2}{|c|}{ Tidak Anemia } & & & & \\
\hline & $\mathbf{n}$ & $\%$ & n & $\%$ & $\mathbf{n}$ & $\%$ & & \\
\hline Tidak mendukung & 110 & 69,2 & 49 & 30,8 & 159 & 100 & \multirow{3}{*}{0,001} & \multirow{3}{*}{$\begin{array}{c}2,544 \\
(1,507-4,294)\end{array}$} \\
\hline Mendukung & 45 & 46,9 & 51 & 53,1 & 96 & 100 & & \\
\hline Total & 155 & 60,8 & 100 & 39,2 & 255 & 100 & & \\
\hline
\end{tabular}

Hasil uji statistik pada tabel 8 diperoleh nilai $p$-value 0,001 , disimpulkan secara statistik ada hubungan yang bermakna antara sikap dengan kejadian anemia pada remaja putri di SMK Negeri 1 Terbanggi Besar Kabupaten
Lampung Tengah Tahun 2012. Berdasarkan hasil analisis diperoleh pula nilai $O R=2,544$, artinya remaja putri yang memiliki sikap tidak mendukung mempunyai risiko 2,544 kali untuk terkena anemia. 
7. Hubungan antara Kejadian Infeksi dengan Kejadian Anemia Defesiensi Zat Besi pada Remaja Putri

Tabel 9. Hubungan antara Kejadian Infeksi dengan Kejadian Anemia Defesiensi Zat Besi pada Remaja Putri

\begin{tabular}{|c|c|c|c|c|c|c|c|c|}
\hline \multirow{3}{*}{ Kejadian Infeksi } & \multicolumn{4}{|c|}{ Kejadian Anemia } & \multirow{2}{*}{\multicolumn{2}{|c|}{ Total }} & \multirow{3}{*}{ p-value } & \multirow{3}{*}{$\begin{array}{c}O R \\
(95 \% C I)\end{array}$} \\
\hline & \multicolumn{2}{|c|}{ Anemia } & \multicolumn{2}{|c|}{ Tidak Anemia } & & & & \\
\hline & $\mathbf{n}$ & $\%$ & $\mathbf{n}$ & $\%$ & $\mathbf{n}$ & $\%$ & & \\
\hline Menderita Penyakit Infeksi & 112 & 66,7 & 56 & 33,3 & 168 & 100 & \multirow{3}{*}{0,011} & \multirow{3}{*}{$\begin{array}{c}2,047 \\
(1,206-3,472)\end{array}$} \\
\hline Tidak Menderita Penyakit Infeksi & 43 & 49,4 & 44 & 50,6 & 87 & 100 & & \\
\hline Total & 155 & 60,8 & 100 & 39,2 & 255 & 100 & & \\
\hline
\end{tabular}

Hasil uji statistik terlihat pada tabel 9 diperoleh nilai $p$-value 0,011 , disimpulkan secara statistik ada hubungan yang bermakna antara kejadian infeksi dengan kejadian anemia pada remaja putri di SMK Negeri 1 Terbanggi Besar Kabupaten Lampung Tengah Tahun 2012.
Berdasarkan hasil analisis diperoleh pula nilai $O R=2,047$, artinya remaja putri yang menderita penyakit infeksi mempunyai risiko 2,047 kali untuk terkena anemia dibandingkan dengan remaja putri yang tidak menderita penyakit infeksi.

\section{Hubungan antara Keadaan Menstruasi dengan Kejadian Anemia Defesiensi Zat Besi pada Remaja Putri}

Tabel 10. Hubungan antara Keadaan Menstruasi dengan Kejadian Anemia Defesiensi Zat Besi pada Remaja Putri

\begin{tabular}{|c|c|c|c|c|c|c|c|c|}
\hline \multirow{3}{*}{ Keadaan Menstruasi } & \multicolumn{4}{|c|}{ Kejadian Anemia } & \multirow{2}{*}{\multicolumn{2}{|c|}{ Total }} & \multirow{3}{*}{$p$-value } & \multirow{3}{*}{$\begin{array}{c}\text { OR } \\
(95 \% C I)\end{array}$} \\
\hline & \multicolumn{2}{|c|}{ Anemia } & \multicolumn{2}{|c|}{ Tidak Anemia } & & & & \\
\hline & $\mathbf{n}$ & $\%$ & $\mathbf{n}$ & $\%$ & $\mathbf{n}$ & $\%$ & & \\
\hline Menstruasi & 124 & 66,3 & 63 & 33,7 & 187 & 100 & \multirow{3}{*}{0,004} & \multirow{3}{*}{$\begin{array}{c}2,349 \\
(1,335-4,135)\end{array}$} \\
\hline Tidak menstruasi & 31 & 45,6 & 37 & 54,4 & 68 & 100 & & \\
\hline Total & 155 & 60,8 & 100 & 39,2 & 255 & 100 & & \\
\hline
\end{tabular}

Pada Tabel 10, hasil uji statistik diperoleh nilai $p$-value 0,004 , disimpulkan secara statistik ada hubungan yang bermakna antara menstruasi dengan kejadian anemia pada remaja putri di SMK Negeri 1 Terbanggi Besar Kabupaten
Lampung Tengah Tahun 2012. Berdasarkan hasil analisis diperoleh pula nilai $O R=2,349$, artinya remaja putri yang menstruasi mempunyai risiko 2,349 kali untuk terkena anemia dibandingkan dengan remaja putri yang tidak menstruasi.

\section{Hubungan antara Asupan Suplemen Zat Besi dengan Kejadian Anemia Defesiensi Zat Besi} pada Remaja Putri

Tabel 11. Hubungan antara Asupan Suplemen Zat Besi dengan Kejadian Anemia Defesiensi Zat Besi pada Remaja Putri

\begin{tabular}{|c|c|c|c|c|c|c|c|c|}
\hline \multirow{3}{*}{ Asupan Suplemen Zat Besi } & \multicolumn{4}{|c|}{ Kejadian Anemia } & \multirow{2}{*}{\multicolumn{2}{|c|}{ Total }} & \multirow{3}{*}{ p-value } & \multirow{3}{*}{$\begin{array}{c}O R \\
(95 \% C I)\end{array}$} \\
\hline & \multicolumn{2}{|c|}{ Anemia } & \multicolumn{2}{|c|}{ Tidak Anemia } & & & & \\
\hline & $\mathbf{n}$ & $\%$ & $\mathbf{n}$ & $\%$ & $\mathbf{n}$ & $\%$ & & \\
\hline Tidak mengkonsumsi & 125 & 66,1 & 64 & 33,9 & 189 & 100 & \multirow{3}{*}{0,005} & \multirow{3}{*}{$\begin{array}{c}2,344 \\
(1,325-4,147)\end{array}$} \\
\hline Mengkonsumsi & 30 & 45,5 & 36 & 54,5 & 66 & 100 & & \\
\hline Total & 155 & 60,8 & 100 & 39,2 & 255 & 100 & & \\
\hline
\end{tabular}

Pada Tabel 11 hasil uji statistik diperoleh nilai $p$-value 0,005 , disimpulkan secara statistik ada hubungan yang bermakna antara asupan suplemen zat besi dengan kejadian anemia pada remaja putri di SMK Negeri 1 Terbanggi Besar Kabupaten Lampung Tengah. Berdasarkan hasil analisis diperoleh pula nilai $O R=2,344$, artinya remaja putri yang tidak mengkonsumsi suplemen zat besi mempunyai risiko 2,047 kali untuk terkena anemia dibandingkan dengan remaja putri yang mengkonsumsi suplemen zat besi. 


\section{ANALISIS MULTIVARIAT} 1. Pemodelan Akhir Hasil Analisis Regresi
Logistik

Tabel 12. Pemodelan Akhir Hasil Analisis Regresi Logistik

\begin{tabular}{cccc}
\hline Variabel & B & $\begin{array}{c}\boldsymbol{p} \text { - } \\
\text { value }\end{array}$ & $\begin{array}{c}\boldsymbol{E x p} \\
(\boldsymbol{B}) / \boldsymbol{O R}\end{array}$ \\
\hline $\begin{array}{c}\text { Indeks Massa } \\
\text { Tubuh }\end{array}$ & 0,158 & 0,034 & 1,172 \\
\hline Pengetahuan & 0,436 & 0,009 & 2,546 \\
\hline $\begin{array}{c}\text { Asupan Suplemen } \\
\text { Zat Besi }\end{array}$ & 0,398 & 0,023 & 1,489 \\
\hline $\begin{array}{c}\text { Keadaan } \\
\text { menstruasi }\end{array}$ & 0,044 & 0,047 & 1,015 \\
\hline
\end{tabular}

Berdasarkan model akhir diatas dapat ditarik kesimpulan bahwa terdapat empat variabel yang berhubungan dengan anemia pada remaja putri di SMKN 1 Terbanggi Besar Kabupaten Lampung Tengah yaitu variabel indeks massa tubuh, pengetahuan, asupan zat besi, keadaan menstruasi.

Hasil penelitian menunjukkan bahwa variabel yang paling dominan berhubungan dengan anemia pada remaja putri di SMKN 1 Terbanggi Besar Kabupaten Lampung Tengah Tahun 2012 adalah variabel pengetahuan dengan koefisien sebesar 0,009 nilai $p=0,002$ dan $O R=2,546$ yang berarti responden yang pengetahuan baik memiliki peluang sebesar 2,546 kali tidak terkena anemia dibandingkan responden dengan pengetahuan kurang.

\section{PEMBAHASAN}

\section{A. ANALISIS UNIVARIAT}

\section{Distribusi Frekuensi Responden berdasarkan Kejadian Anemia}

Berdasarkan hasil penelitian diketahui distribusi frekuensi kejadian anemia responden lebih tinggi pada kategori anemia yaitu sebanyak 155 orang $(60,8 \%)$. Hal ini sejalan dengan penelitian Weliyati (2010) distribusi frekuensi kejadian anemia responden lebih tinggi pada kategori anemia yaitu sebanyak $77,1 \%$.

Anemia adalah suatu keadaan di mana kadar haemoglobin lebih rendah dari normal. Pada pria, haemoglobin normal adalah 14-18 gr\% sedangkan pada wanita. Haemoglobin normal adalah 12-16 gr\% (Proverawati, 2011).

Berdasarkan teori menurut peneliti tingginya proporsi keadaan anemia responden di SMK Negeri 1 Terbanggi Besar dalam kategori anemia faktor kemungkinan pertama disebabkan karena rendahnya pendidikan ibu remaja putri yang pada akhirnya menyebabkan pengetahuan ibu remaja putri mengenai anemia menjadi rendah sehingga ibu kurang memperhatikan kesehatan remaja putri khususnya mengenai anemia, faktor kemungkinan kedua rendahnya pendapatan keluarga remaja putri untuk membeli makanan-makanan bergizi sehingga menyebabkan remaja putri kurang mendapatkan asupan zat besi, faktor kemungkinan ketiga tingginya kebiasaan remaja putri minum teh, dan terkena penyakit infeksi.

\section{Distribusi Frekuensi Faktor-faktor yang Mempengaruhi Kejadian Anemia \\ Berdasarkan tabel 2 diketahui distribusi} frekuensi pendidikan ibu repsonden lebih dominan pada kategori rendah yaitu sebanyak 161 orang $(63,1 \%)$. Hasil ini sejalan dengan penelitian Farida (2006), hasil penelitian didapat $76,4 \%$ pendidikan ibu rendah. Notoatmodjo (2005) mengartikan pendidikan secara umum adalah segala upaya yang direncanakan untuk mempengaruhi orang lain baik individu, kelompok atau masyarakat, sehingga mereka melakukan apa yang diharapkan oleh perilaku pendidikan. Menurut Sulaeman (2007) pendidikan juga berkaitan dengan tingkat pemahaman seseorang akan sakit. Pendidikan berpengaruh pada cara berfikir, tindakan dan pengambilan keputusan dalam menggunakan pelayanan kesehatan, semakin tinggi pendidikan ibu maka semakin baik pula pengetahuannya tentang kesehatan. Latar belakang pendidikan sesorang merupakan salah satu unsur penting yang dapat memengaruhi keadaan gizinya karena dengan tingkat pendidikan yang lebih tinggi diharapkan pengetahuan atau informasi tentang gizi yang dimiliki menjadi lebih baik. Sering timbulnya masalah gizi karena ketidaktahuan atau kurang informasi tentang gizi yang memadai (Berg, 1987 dalam Departemen Gizi dan Kesehatan Masyarakat FKUI, 2007).

Berdasarkan tabel 2 diketahui distribusi frekuensi kebiasaan minum teh responden lebih tinggi pada kategori minum teh yaitu sebanyak 187 orang $(73,3 \%)$. Penyebab dari anemia defisiensi besi adalah dikarenakan asupan dan serapan zat besi yang tidak adekuat, yaitu dengan kebiasaan mengkonsumsi makanan yang dapat mengganggu penyerapan zat besi seperti teh secara bersamaan pada waktu makan. Menurut Proverawati (2011) minum teh paling tidak sejam sebelum atau setelah makan akan mengurangi daya serap sel darah terhadap zat besi sebesar $64 \%$. Pengurangan daya serap akibat teh ini lebih 
tinggi daripada akibat sama yang ditimbulkan oleh minum segelas kopi setelah makan. Kopi mengurangi daya serap hanya $39 \%$. Pengurangan daya serap zat besi itu di akibatkan oleh tanin dalam teh. Sifat zat ini mengikat mineral. Lapisan tipis dipermukaan air teh akan terlihat apabila air yang dipergunakan banyak mengandung mineral (air sadah). Lapisan tipis tersebut sesungguhnya adalah hasil reaksi antara mineral dengan tanin, membentuk tanat. Apabila tanin tersebut bereaksi dengan mineral-mineral dalam makanan, maka mineral tersebut akhirnya tidak dapat digunakan tubuh dan terbuang bersama feses.

Berdasarkan tabel 2 diketahui distribusi frekuensi pendapatan ibu responden lebih dominan pada kategori rendah yaitu sebanyak 194 orang $(76,1 \%)$. Hasil ini sejalan dengan penelitian Farida (2006), hasil penelitian didapat $76,4 \%$ responden kategori ekonomi rendah. Menurut Supariasa (2002), tingkat ekonomi (pendapatan) masyarakat Indonesia yang masih tergolong rendah membuat penyediaan pangan yang kurang baik bagi keluarga. Melihat kondisi ekonomi masyarakat saat ini, kebutuhan zat besi sulit sekali terpenuhi melalui konsumsi makanan yang kaya akan zat besi, karena umumnya bahan makanan ini harganya cukup mahal. Hal ini mempengaruhi pemenuhan asupan gizi yang akan mempengaruhi pula dengan pemenuhan kebutuhan zat besi.

Berdasarkan tabel 2 diketahui distribusi frekuensi pengetahuan responden lebih dominan pada kategori rendah yaitu sebanyak 158 orang $(62,0 \%)$. Hasil ini sejalan dengan penelitian Farida (2006), hasil penelitian didapat 66,2\% pengetahuan responden tentang anemia kurang baik. Menurut Sulaeman (2007) orang dengan pendidikan formal yang tinggi cenderung akan mempunyai pengetahuan yang lebih tinggi dibandingkan dengan orang yang mempunyai tingkat pendidikan formal yang lebih rendah, karena akan lebih mampu dan mudah memahami arti dan pentingnya kesehatan.

Berdasarkan tabel 2 diketahui distribusi frekuensi sikap responden lebih dominan pada kategori tidak mendukung yaitu sebanyak 159 orang $(62,4 \%)$. Hasil ini sejalan dengan penelitian Weliyati (2010) diketahui sebanyak $70,2 \%$ mengalami anemia pada remaja putri mempunyai sikap tidak mendukung terhadap anemia. Sikap adalah reaksi atau respon seseorang yang masih tertutup terhadap stimulus ataupun objek serta pandangan atau perasaan yang disertai kecenderungan untuk bertindak sesuai objek tersebut (Notoatmodjo, 2005).

Berdasarkan tabel 2 diketahui distribusi frekuensi kejadian infeksi responden lebih dominan pada kategori menderita penyakit infeksi yaitu sebanyak 168 orang $(65,9 \%)$. Hasil ini sejalan dengan penelitian Weliyati (2010) responden kategori menderita penyakit infeksi yaitu sebanyak $68,2 \%$. Perdarahan patologis akibat penyakit atau infeksi parasit seperti cacingan dan saluran pencernaan juga berhubungan positif terhadap anemia. Darah yang hilang akibat infeksi cacing bervariasi antara 2-100 cc/hari, tergantung beratnya infestasi. Anemia yang dikarenakan infeksi, seperti malaria, ISPA dan cacingan terjadi secara cepat saat cadangan $\mathrm{Fe}$ tidak mencukupi peningkatan kebutuhan Fe (Departemen Gizi dan Kesehatan Masyarakat, FKUI, 2007).

Berdasarkan tabel 2 diketahui distribusi frekuensi asupan zat besi responden lebih dominan pada kategori tidak mengkonsumsi yaitu sebanyak 189 orang $(74,1 \%)$. Hasil ini sejalan dengan penelitian Weliyati (2010) responden kategori tidak mengkonsumsi asupan suplemen zat besi yaitu sebanyak 60,2\%. Menurut Arisman (2004) masa pertumbuhan seperti anak-anak dan remaja juga meningkatkan kebutuhan tubuh akan zat besi. Hal ini dikarenakan pada masa remaja terjadi puncak-puncak pertumbuhan tercepat yang membutuhkan lebih banyak zat besi. Kebutuhan zat besi dan kalsium yang paling mencolok karena kedua mineral ini merupakan komponen penting pembentuk tulang dan otot.

Berdasarkan tabel 2 diketahui distribusi frekuensi keadaan menstruasi responden lebih dominan pada kategori menstruasi yaitu sebanyak 187 orang $(73,3 \%)$. Hasil ini sejalan dengan penelitian Weliyati (2010) distribusi frekuensi menstruasi responden lebih tinggi pada kategori menstruasi yaitu sebanyak $67,4 \%$. Kehilangan darah terjadi melalui menstruasi. Rata-rata seorang wanita mengeluarkan darah $27 \mathrm{ml}$ setiapa siklus menstruasi 28 hari. Diduga 10\% wanita kehilangan darah lebih dari $80 \mathrm{ml}$ perbulan. Banyaknya darah yang keluar berperan pada kejadian anemia karena wanita tidak mempunyai persediaan $\mathrm{Fe}$ yang cukup dan absorbsi $\mathrm{Fe}$ kedalam tubuh tidak dapat menggantikan kehilangan $\mathrm{Fe}$ saat menstruasi (Departemen Gizi dan Kesehatan Masyarakat FKUI, 2007).

\section{B. ANALISIS BIVARIAT}

\section{Hubungan Pendapatan Keluarga dengan Kejadian Anemia}

Hasil uji statistik diperoleh nilai $p$-value 0,004, disimpulkan secara statistik ada hubungan yang signifikan antara pendapatan keluarga dengan kejadian anemia. Berdasarkan hasil 
analisis diperoleh pula nilai $O R=2,442$, artinya remaja putri yang pendapatan keluarga rendah mempunyai peluang 2,442 kali untuk terkena anemia dibandingkan dengan remaja putri yang pendapatan keluarganya tinggi.

Pendapatan keluarga dinilai berdasarkan besarnya pendapatan rata-rata setiap bulan keluarga responden, kemudian dibagi jumlah keluarga yang masih menjadi tanggungan, lalu hasilnya di bandingkan dengan UMK Lampung Tengah. Menurut Supariasa (2002), tingkat ekonomi (pendapatan) masyarakat Indonesia yang masih tergolong rendah membuat penyediaan pangan yang kurang baik bagi keluarga. Melihat kondisi ekonomi masyarakat saat ini, kebutuhan zat besi sulit sekali terpenuhi melalui konsumsi makanan yang kaya akan zat besi, karena umumnya bahan makanan ini harganya cukup mahal. Hal ini mempengaruhi pemenuhan asupan gizi yang akan mempengaruhi pula dengan pemenuhan kebutuhan zat besi.

Menurut Sulaeman (2007) pendapatan keluarga merupakan salah satu pengubah ekonomi yang cukup dominan sebagai determinan konsumsi pangan. Pendapatan/penghasilan yang kecil tidak dapat member cukup makan pada anggota keluarga yang dapat mempengaruhi remaja dalam mengkonsumsi zat gizi dan pengadaan aneka ragam makanan yang berdampak pada kurangnya asupan zat besi. Rendahnya asupan zat besi kedalam tubuh yang berasal dari konsumsi zat besi dari maknan sehari-hari merupakan salah satu penyebab terjadinya anemia.

Uraian di atas sejalan dengan hasil penelitian Farida (2006) yang menyatakan bahwa kejadian anemia pada remaja putri dengan keluarga berpendapatan rendah lebih besar dibandingkan keluarga berpendapatan tinggi. Uji Chi-Square menunjukkkan ada hubungan pendapatan dengan kejadian anemia pada remaja putri $(\mathrm{p}=0,001)$. Demikian pula penelitian Isniati (2007) yang menyatakan $80-90 \%$ remaja putri dengan pendapatan rendah memiliki kadar $H b$ kurang dari $12 \mathrm{~g} / \mathrm{dl}$.

Berdasarkan hasil penelitian dan teori di atas maka peneliti dapat menyimpulkan bahwa responden dengan pendapatan keluarga rendah lebih cenderung anemia dibandingkan dengan remaja putri yang pendapatan keluarganya tinggi, hal ini disebabkan karena keluarga dengan penghasilan tinggi memiliki kemampuan untuk membeli makanan serta memudahkan dalam memilih bahan makanan atau jenis hidangan yang akan disajikan. Peningkatan pendapatan akan berpengaruh pada perbaikan kesehatan dan kondisi keluarga yang selanjutnya berhubungan dengan gizi termasuk diantaranya status anemia.

\section{Hubungan Pendidikan Ibu dengan Kejadian Anemia}

Hasil uji statistik diperoleh nilai $p$-value 0,002 , disimpulkan secara statistik ada hubungan yang signifikan antara pendapatan keluarga dengan kejadian anemia. Berdasarkan hasil analisis diperoleh pula nilai $O R=2,349$, artinya remaja putri yang pendidikan ibunya rendah mempunyai peluang 2,349 kali untuk terkena anemia dibandingkan dengan remaja putri yang pendidikan ibunya tinggi.

Sulaeman (2007) berpendapat bahwa pendidikan ibu merupakan faktor yang sangat penting. Tingkat pendidikan ibu dapat menentukan pengetahuan dan keterampilan dalam menentukan menu keluarga yang selanjutnya akan berpengaruh terhadap status kesehatan keluarganya termasuk kejadian anemia pada anaknya. Menurut Isniati (2007) pendidikan berpengaruh pada cara berfikir, tindakan dan pengambilan keputusan dalam menggunakan pellayanan kesehatan, semakin tinggi pendidikan ibu maka akan semakin baik pula pengetahuannya tentang kesehatan. Seseorang yang berpendidikan tinggi akan lebih memahami akan sakit dan dengan segera untuk mencari tempat pelayanan kesehatan yang modern. Pendidikan yang rendah menyebabkan seseorang acuh tak acuh terhadap rogram kesehatan, sehingga mereka tidak mengenal bahaya yang mungkin terjadi walaupun ada sarana yang belum tentu mereka tahu menggunakannya.

Berdasarkan hasil penelitian dan teori di atas maka dapat disimpulkan bahwa remaja putri yang pendidikan ibunya rendah cenderung anemia dibandingkan remaja putri yang pendidikan ibunya tinggi, sehingga perlu dipertimbangkan bahwa faktor pendidikan turut pula menentukan mudah tidaknya seseorang menyerap dan memahami pengetahuan gizi yang mereka peroleh. Hal ini bisa dijadikan landasan untuk membedakan metode penyuluhan yang tepat. Dalam kepentingan gizi keluarga, pendidikan amat diperlukan agar seseorang lebih tanggap terhadap adanya masalah gizi didalam keluarga dan bisa mengambil tindakan secepatnya.

\section{Hubungan Kebiasaan Minum Teh dengan Kejadian Anemia}

Hasil uji statistik diperoleh nilai $p$-value 0,002 , disimpulkan secara statistik ada hubungan yang signifikan antara kebiasaan minum teh dengan kejadian anemia. Berdasarkan hasil 
analisis diperoleh pula nilai $O R=2,554$ artinya remaja putri yang minum teh mempunyai peluang 2,554 kali untuk terkena anemia dibandingkan dengan remaja putri yang tidak minum teh.

Menurut Almatsier (2003), terdapat beberapa makanan yang mengandung zat penghambat absorbsi besi diantaranya adalah beberapa jenis sayuran yang mengandung asam oksalat, beberapa jenis serelia dan protein kedelai yang mengandung asam fitrat, serta teh dan kopi yang mengandung tanin. Bila besi tubuh tidak terlalu tinggi, sebaiknya tidak minum teh atau kopi pada waktu makan. Menurut Proverawati (2011) Minum teh paling tidak sejam sebelum atau setelah makan akan mengurangi daya serap sel darah terhadap zat besi sebesar $64 \%$. Pengurangan daya serap akibat teh ini lebih tinggi daripada akibat sama yang ditimbulkan oleh minum segelas kopi setelah makan. Kopi mengurangi daya serap hanya $39 \%$. Bila kita makan menu standar plus segelas teh, zat besi yang diserap hanya setengah dari makanan yang kita makan. Pengurangan daya serap zat besi itu diakibatkan oleh zat tanin dalam teh. Sifat zat ini mengikat mineral. Anda mungkin sering melihat adanya lapisan tipis di permukaan air teh, bila air yang dipergunakan banyak mengandung mineral (air sadah). Lapisan tipis tersebut sesungguhnya adalah hasil reaksi antara mineral dengan tanin, membentuk tanat. apabila tanin tersebut bereaksi dengan mineral-mineral dalam makanan, maka mineral tersebut akhirnya tidak dapat digunakan tubuh dan terbuang bersama feses.

Berdasarkan hasil penelitian dan teori diatas dapat disimpulkan bahwa salah satu penyebab timbulnya anemia defisiensi besi dikarenakan penyerapan zat besi didalam tubuh tidak optimal. Penyerapan yang tidak optimal ini dikarenakan adanya zat penghambat seperti tannin yang terdapat didalam teh. Teh adalah minuman yang saat ini sering dikonsumsi pada saat makan,hal ini mengakibatkan besarnya resiko anemia defisiensi zat besi. Oleh sebab itu sangatlah penting peran petugas kesehatan dalam memberikan penyuluhan terkait faktor penyebab anemia yang salah satunya adalah mengkonsumsi teh pada saat makan. Perlu diinformasikan pada remaja putri bahwa penggunaan teh bisa digantikan dengan air jeruk yang banyak mengandung vitamin $\mathrm{C}$ sehingga memudahkan penyerapan zat besi. Dengan diketahuinya hal tersebut, maka akan merubah kebiasaan remaja putri mengkonsumsi teh pada saat makan.

\section{Hubungan Indeks Massa Tubuh dengan Kejadian Anemia}

Hasil uji statistik diperoleh nilai $p$-value 0,002 , disimpulkan secara statistik ada hubungan yang signifikan antara pendapatan keluarga dengan kejadian anemia. Berdasarkan hasil analisis diperoleh pula nilai $O R=2,329$, artinya remaja putri yang indeks massa tubuhnya tidak normal mempunyai peluang 2,329 kali untuk terkena anemia dibandingkan dengan remaja putri yang indeks massa tubuhnya normal.

Status gizi merupakan cerminan kecukupan konsumsi zat gizi masa-masa sebelumnya yang berarti bahwa status gizi saat ini merupakan hasil kumulasi konsumsi makanan sebelumnya. Salah satu pengukuran antropometri untuk mengetahui keadaan gizi adalah dengan mengukur berat badan (BB) dan tinggi badan (TB) dengan menggunakan indeks massa tubuh yaitu hasil pembagian $\mathrm{BB}$ dalam $\mathrm{kg}$ dengan kuadrat TB dalam satuan $\mathrm{m}^{2}\left(\mathrm{BB} / \mathrm{TB}^{2}\right)$. Indeks massa tubuh (IMT) merupakan salah satu indiktor status gizi karena dapat manyatakan baik pengukuran tinggi badan dengan koefisien variasi sangat kecil antara 1-2\% dibandingkan pengukuran antropometri lain (Supariasa, 2002). Terdapat tiga jenis kekurangan gizi, yaitu kekurangan secara kualitatif, kekurangan secara kuantitatif dan kekurangan keduanya. Apabila kuantitas nutrient cukup, tetapi kualitasnya kurang maka orang dapat menderita berbagai kekurangan vitamin, mineral, protein, dan lainlainnya. Masalah status gizi pada remaja di Indonesia meliputi kurang zat gizi makro dan kurang zat gizi mikro. Status gizi merupakan gambaran secara makro akan zat gizi dalam tubuh kita, termasuk salah satunya adalah zat besi. Bila status gizi tidak normal atau kurang dapat merupakan salah satu faktor resiko terjadinya anemia.

Hal ini sejalan dengan hasil penelitian Sulaeman (2007) yang menunjukkan bahwa sebanyak $69,0 \%$ remaja putri dengan status gizi tidak normal mengalami anemia.

Berdasarkan hasil penelitian dan teori di atas dapat disimpulkan bahwa Indeks massa Tubuh remaja putri masih banyak yang tidak normal, olehkarena itu peran petugas kesehatan dan juga orang tua khususnya ibu untuk memberikan pendidikan kesehatan terkait pola makan remaja putri sehari-hari. Pola makan akan mempengaruhi Tinggi badan dan berat badan, pola makan ataupun diit yang salah akan mengakibatkan pertumbuhan pada remaja tidak optimal. 


\section{Hubungan Pengetahuan dengan Kejadian Anemia}

Hasil uji statistik diperoleh nilai $p$-value 0,002 , disimpulkan secara statistik ada hubungan yang signifikan antara pengetahuan remaja putri dengan kejadian anemia. Berdasarkan hasil analisis diperoleh pula nilai $O R=2,298$, artinya remaja putri yang pengetahuan kurang mempunyai peluang 2,298 kali untuk terkena anemia dibandingkan dengan remaja putri yang pengetahuan baik.

Pengetahuan adalah merupakan hasil dari tahu dan ini setelah orang melakukan penginderaan terhadap obyek tertentu. Penginderaan terjadi melalui panca indera manusia, yakni indera penglihatan, pendengaran, penciuman, rasa dan raba. Sebagaian besar pengetahuan manusia diperoleh melalui mata dan telinga (Notoatmodjo, 2005). Sering timbulnya masalah gizi karena ketidaktahuan atau kurang informasi rentang gizi yang memadai (Berg, 1987 dalam Departemen Gizi dan Kesehatan Masyarakat FKUI, 2007).

Pentingnya pengetahuan gizi terhadap konsumsi didasari atas tiga kenyataan yaitu status gizi yang cukup adalah penting bagi kesehatan dan kesejahteraan, setiap orang hanya akan cukup gizi yang diperlukan jika makanan yang dimakan mampu menyediakan zat gizi yang diperlukan untuk pertumbuhan tubuh yang optimal, ilmu gizi memberikan fakta-fakta yang perlu sehingga penduduk dapat belajar menggunakan pangan dengan baik bagi perbaikan gizi (Suhardjo, 1986 dalam Departemen gizi dan Kesehatan Masyarakat FKUI, 2007).

Hal ini sejalan dengan Penelitian Weliyati (2010) yang menunjukkan adanya hubungan antara pengetahuan anemia dengan kejadian anemia di SMAN Kota Metro dengan nilai $p=0,001$ dan nilai $O R=0,317$. Hal ini berarti pengetahuan remaja putri yang rendah merupakan protektif terhadap anemia sekitar sepertiga $(0,371)$ dibandingkan yang berpengetahuan baik.

Berdasarkan hasil penelitian dan teori di atas dapat disimpulkan bahwa pengetahuan seseorang dapat mempengaruhi terjadinnya anemia. Hal ini karena pengetahuan seseorang akan mempengaruhi perilakunya termasuk pola hidup dan kebiasaan makan. Kurangnya pengetahuan tentang anemia, tanda-tanda, dampak dan pencegahannya mengakibatkan remaja mengkonsumsi makanan yang kandungan zat besinya sedikit sehingga asupan zat besi yang dibutuhkan remaja putri tidak terpenuhi. Hal ini meningkatkan resiko remaja putri terkena anemia. Untuk itu penanggulangan anemia pada remaja putri hendaknya mulai diprioritaskan sehingga perlu adanya program khusus penanggulangan anemia. Program penanggulangannya bisa berupa penyuluhan pada remaja putri tentang anemia, dampak anemia, pencegahan anemia dan cara penanggulangan anemia, sehingga remaja putri dapat mencegah diri untuk terhindar dari anemia.

\section{Hubungan Sikap dengan kejadian Anemia}

Hasil uji statistik diperoleh nilai $p$-value 0,001, disimpulkan secara statistik ada hubungan yang signifikan antara sikap dengan kejadian anemia. Berdasarkan hasil analisis diperoleh pula nilai $O R=2,544$, artinya remaja putri yang memiliki sikap tidak mendukung mempunyai peluang 2,544 kali untuk terkena anemia dibandingkan dengan remaja putri yang sikapnya mendukung.

Sikap adalah merupakan reaksi atau respons seseorang yang masih tertutup terhadap suatu stimulus atau obyek (Notoatmodjo, 2005). Sikap remaja putri terhadap anemia adalah tanggapan atau reaksi remaja putri terhadap pernyataan mengenai anemia, yang meliputi gejala dan tanda, penyebab, bahaya dan akibat serta upaya pencegahan.

Hal ini sejalan dengan hasil penelitian Weliyati (2010) dimana diketahui sebanyak $18,2 \%$ mengalami anemia pada remaja putri mempunyai sikap tidak mendukung terhadap anemia. Demikian pula penelitian Farida (2006) diketahui bahwa kejadian anemia pada remaja putri dengan sikap yang kurang baik lebih banyak dibandingkan mereka yang memiliki sikap baik.

Sikap secara nyata menunjukkan konotasi adanya kesesuaian reaksi terhadap stimulus tertentu yang dalam kehidupan sehari-hari merupakan reaksi yang bersifat emosional terhadap stimulus sosial. Sikap merupakan kesiapan untuk bereaksi terhadap objek di lingkungan tertentu sebagai suatu penghayatan terhadap objek (Notoatmodjo, 2005).

Dari hasil penelitian dan teori diatas dapat disimpulkan bahwa sikap mempengaruhi terbentuknya perilaku positif ataupun perilaku negatif. Sikap positif akan mewujudkan perilaku positif pula. Sehingga sangat penting peran petugas kesehatan untuk memberikan penyuluhan terkait anemia untuk menimbulkan sikap positif siswi terhadap anemia. Begitupula peran guru sangat penting untuk memasukkan program penanggulangan anemia di dalam pendidikan disekolah sebagai suatu pengetahuan sehingga dapat memberikan sikap positif dalam diri siswi. 


\section{Hubungan Kejadian Infeksi dengan Kejadian Anemia}

Hasil uji statistik diperoleh nilai $p$-value 0,011 , disimpulkan secara statistik ada hubungan yang signifikan antara kejadian infeksi dengan kejadian anemia. Berdasarkan hasil analisis diperoleh pula nilai $O R=2,047$, artinya remaja putri yang menderita penyakit infeksi mempunyai peluang 2,047 kali untuk terkena anemia dibandingkan dengan remaja putri yang tidak menderita penyakit infeksi.

Perdarahan patologis akibat penyakit/infeksi parasit seperti cacingan dan saluran pencernaan juga berhubungan positif terhadap anemia. Darah yang hilang akibat infestasi cacing bervariasi antara 2-100 cc/hari, tergantung beratnya infestasi. Anemia yang disebabkan karena penyakit infeksi, seperti seperti malaria, ISPA dan cacingan terjadi secara cepat saat cadangan $\mathrm{Fe}$ tidak mencukupi peningkatan kebutuhan Fe. (Departemen Gizi dan Kesehatan Masyarakat, FKUI, 2007).

Menurut Arisman (2004) kehilangan besi dapat pula diakibatkan oleh infestasi parasit seperti cacing tambang, Schistoma, dan mungkin pula Trichuris trichura. Hal ini lazim terjadi dinegara tropis, lembab serta keadaan sanitasi yang buruk. Penyakit kronis seperti ISPA, malaria dan cacingan akan memperberat anemia. Penyakit infeksi akan menyebabkan gangguan gizi melalui beberapa cara yaitu menghilagkan bahan makanan melalui muntah-muntah dan diare serta dapat menurunkan nafsu makan.. Infeksi juga dapat menyebabkan pembentukan $\mathrm{Hb}$ terlalu lambat. Penyakit diare dan ISPA dapat menganggu nafsu makan yang akhirnya dapat menurunkan tingkat konsumsi gizi.

Hal ini sejalan dengan hasil penelitian Farida (2006) yang menyatakan ada hubungan kejadian infeksi dengan kejadian anemia $(\mathrm{p}=0,001)$. Demikian pula hasil penelitian Isniati (2007) yang menyatakan ada hubungan infeksi dengan kejadian anemia.

Berdasarkan hasil penelitian dan teori diatas dapat disimpulkan bahwa kejadian anemia pada remaja putri yang menderita infeksi dalam satu bulan terakhir jauh lebih besar disbanding dengan remaja putri yag tidak menderita infeksi, oleh karena itu sangat penting adanya peran petugas kesehatan dalam memberikan penyuluhan terkait faktor-faktor penyebab anemia yang salah satunya adalah penyakit infeksi, agar remaja putri dapat menjaga kesehatan dan juga asupan nutrisi yang adekuat sehingga dapat terhindar dari penyakit infeksi. Penting pula untuk mensosialisasikan asupan suplemen zat besi terhadap remaja putri pada saat menstruasi, pada saat menstruasi meningkatkan resiko terjadinya anemia 3,37 kali dibandingkan remaja putri yang tidak menstruasi. Keadaan anemia mengakibatkan menurunnya imunitas sehingga memperbesar resiko terjadinya penyakit infeksi.

\section{Hubungan Asupan Suplemen Zat Besi dengan Kejadian Anemia}

Hasil uji statistik diperoleh nilai $p$-value 0,005 , disimpulkan secara statistik ada hubungan yang signifikan antara kejadian infeksi dengan kejadian anemia. Berdasarkan hasil analisis diperoleh pula nilai $O R=2,344$, artinya remaja putri yang tidak mengkonsumsi suplemen zat besi mempunyai peluang 2,047 kali untuk terkena anemia dibandingkan dengan remaja putri yang mengkonsumsi suplemen zat besi.

Anemia defesiensi $\mathrm{Fe}$ dicegah dengan memelihara keseimbangan antara asupan $\mathrm{Fe}$ dengan kebutuhan dan kehilangan Fe. Jumlah Fe yang dibutuhkan untuk memelihara keseimbangan ini bervariasi antara satu wanita dengan lainnya, tergantung pada riwayat reproduksi dan jumlah kehilangan darah selama menstruasi. Peningkatan konsumsi $\mathrm{Fe}$ untuk memenuhi kebutuhan $\mathrm{Fe}$ dilakukan melalui peningkatan konsumsi makanan mengandung heme iron dan meminimalkan konsumsi makanan yang mengandung faktor penghambat absorbsi Fe. Jika kebutuhan Fe tidak cukup terpenuhi dari diet makanan, dapat ditambah dengan suplemen Fe terutama bagi wanita hamil dan masa nifas dan remaja yang dalam proses pertumbuhan (Winkjosastro, 2008).

Suplementasi Fe adalah salah satu strategi untuk meningkatkan intake $\mathrm{Fe}$ yang berhasil hanya jika individu mematuhi aturan konsumsinya. Bentuk strategi lain yang digunakan untuk meningkatkan kepatuhan mengkonsumsi $\mathrm{Fe}$ adalah melalui pendidikan tentang pentingnya suplementasi $F e$ dan efek samping akibat minum Fe (Proverawati, 2011).

Hal ini tidak sejalan dengan hasil penelitian Weliyati (2010) yang menyatakan bahwa tidak ada hubungan antara konsumsi suplemen zat besi dengan kejadian anemia pada remaja putri.

Dari hasil penelitian dan teori di atas dapat disimpulkan bahwa anemia kekurangan besi besi terjadi karena pola konsumsi makanan masyarakat Indonesia yang masih didominasi sayuran sebagai sumber besi yang sulit diserap, sedangkan daging dan bahan pangan hewani sebagai sumber besi yang baik dikonsumsi dalam jumlah yang kurang. Rendahnya konsumsi zat besi juga disebabkan karena masih rendahnya 
kemampuan keluarga untuk menyediakan sumber zat besi khususnya protein hewai dalam menu makanan sehari-hari, selain itu dikarenakan pula konsumsi makanan responden masih monoton, kebiasaan responden mengkonsumsi teh setelah makan yang juga berdampak pada rendahnya penyerapan zat besi dalam tubuh responden. Untuk itu sangat penting peran petugas kesehatan setempat dalam mensosialisasikan suplemen tablet $\mathrm{Fe}$ bagi remaja putri, terutama pada saat menstruasi, karena besi merupakan mikroelemen yang esensial bagi tubuh, sebagai faktor utama pembentuk hemoglobin (Almatsier, 2003).

\section{Hubungan Keadaan Menstruasi dengan Kejadian Anemia}

Hasil uji statistik diperoleh nilai $p$-value 0,004, disimpulkan secara statistik ada hubungan yang signifikan antara kejadian infeksi dengan kejadian anemia. Berdasarkan hasil analisis diperoleh pula nilai $O R=2,349$, artinya remaja putri yang menstruasi mempunyai peluang 2,349 kali untuk terkena anemia dibandingkan dengan remaja putri yang tidak menstruasi.

Menstruasi adalah runtuhnya jaringan sel endometrium akibat pengaruh perubahan siklik keseimbangan hormonal reproduksi waita (Winkjosastro, 2008). Serangkaian kejadian menstruasi yang dialami wanita setiap bulannya akan membentuk pola menstruasi yang meliputi lamanya, banyaknya dan siklus.

Kehilangan darah terjadi melalui menstruasi. Rata-rata seorang wanita mengeluarkan darah $27 \mathrm{ml}$ setiap siklus menstruasi 28 hari. Diduga $10 \%$ wanita kehilangan darah lebih dari $80 \mathrm{ml}$ perbulan. Bayaknya darah yang keluar berperan pada kejadian anemia karena wanita tidak mempunyai persediaan $\mathrm{Fe}$ yang cukup dan absorbs $\mathrm{Fe}$ ke dalam tubuh tidak dapat menggantikan hilangnya Fe saat menstruasi (Departemen Gizi Dan Kesehatan Masyarakat FKUI, 2007). Menurut Winkjosastro, (2008) pada wanita dengan anemia defesiensi besi jumlah darah haid lebih dari $80 \mathrm{cc}$ dianggap patologik.

Hal ini sejalan dengan hasil penelitian Weliyati (2010) dimana diketahui bahwa ada hubungan antara lama menstruasi dengan kejadian anemia. Hasil analisis diperoleh nilai $O R=3,37$ yang berarti bahwa remaja putri dengan pola menstruasi lebih lama (>7 hari) secara statistik memiliki peluang atau resiko mengalami anemia 3,37 kali lebih besar dibandingkan dengan responden yang pola menstruasinya lebih singkat. Sedangkan hasil analisis hubungan antara siklus menstruasi dengan kejadian anemia diperoleh sebanyak $44,4 \%$ responden dengan siklus menstruasi lebih panjang, yaitu $>21$ hari mengalami anemia. Demikian pula hasil analisis banyaknya menstruasi dengan kejadian anemia, diketahui bahwa ada sebanyak $21,7 \%$ responden dengan perdarahan menstruasi lebih banyak, yaitu mengganti pembalut $>3$ kali/ hari mengalami anemia.

Berdasarkan hasil penelitian dan teori di atas dapat disimpulkan bahwa sangat penting adanya program penanggulagan anemia pada remaja putri dengan pemberian tablet $\mathrm{Fe} 1 \mathrm{x} 60$ $\mathrm{mg}$ perhari selama menstruasi dan juga memperhatikan asupan nutrisi yang banyak mengandung zat besi.

\section{ANALISIS MULTIVARIAT}

Hasil seleksi bivariat menunjukkan bahwa dari 9 variabel yang diteliti dapat dimasukkan seluruhnya kedalam analisis multivariat. Hasil dari analisis multivariate terdapat variabel yang dikeluarkan yaitu variabel pendidikan ibu, variabel kebiasaan minum teh dan variabel sikap, sehingga hanya 6 variabel yang masuk ke dalam analisis multivariat. Berdasarkan hasil model terakhir multivariate didapatkan bahwa dari 10 variabel yang diteliti, ternyata variabel yang paling dominan atau paling bermakna adalah variabel pengetahuan dengan hasil $p$-value $=0,008$ dengan $O R=4,576$, berarti remaja putri yang pengetahuannya kurang memiliki peluang 4,576 kali untuk dapat terkena anemia dibandingkan remaja putri yang pengetahuannya baik.

Hasil penelitian diatas menggambarkan bahwa masih banyak responden yang pengetahuannya kurang tentang anemia sehingga banyak yag mengalami kejadian anemia. Salah satu faktor masih tingginya angka kejadian anemia adalah kurangnya pengetahuan tentang anemia, kurangnya pengetahuan di sini adalah ketidaktahuan akan tanda-tanda dan gejala serta dampak yang timbul oleh anemia, akibatnya kalaupun individu tersebut terkena anemia ia tidak merasa "sakit". Menurut Proverawati (2011) salah satu penyebab anemia gizi besi adalah karena minimnya pengetahuan tentang anemia gizi besi. Dilihat secara teori faktor yang mempengaruhi seseorang akan anemia gizi besi yaitu pendidikan. Pendidikan adalah suatu usaha untuk mengembangkan kepribadian dan kemampuan di dalam dan diluar sekolah dan berlangsung seumur hidup. Pendidikan mempengaruhi proses belajar, makin tinggi pendidikan seseorang makin mudah orang tersebut untuk menerima informasi. Dengan pendidikan tinggi maka seseorang akan cenderung untuk mendapatkan informasi, baik 
dari orang lain maupun dari media massa. Semakin banyak informasi yang masuk semakin banyak pula pengetahuan yang didapat tentang kesehatan.

Menurut Proverawati (2011) menyatakan bahwa beberapa faktor yang mempengaruhi terjadinya anemia adalah kurangnya pengetahuan remaja tentang anemia, pemeliharaan kesehatan, resistensi tablet besi dan komunikasi yang kurang tentang pentingnya suplemen tablet besi terutama pada saat menstruasi. Pengetahuan seseorang dapat diperoleh dengan berbagai usaha, baik sengaja maupun secara kebetulan. Usaha yang dilakukan dengan sengaja meliputi berbagai metode dan konsep baik melalui proses pendidikan maupun melalui pengalaman. Pengetahuan seseorang dapat dioperoleh melalui kurikulum pendidikan disekolah terkait anemia gizi besi, penyuluhan tentang anemia gizi besi, maupun dari berbagai sumber seperti media cetak seperti buku, majalah, koran, poster. Dari media elektronik radio, televisi, film dan lainnya, berperan penting dalam memperoleh informasi baik tentang anemia gizi besi. Informasi tentang anemia gizi besi juga dapat diperoleh dari tenaga kesehatan setempat. Seorang tenaga kesehatan dituntut untuk dapat memberikan pendidikan kesehatan, dalam hal ini pendidikan anemia gizi besi kepada masyarakat, individu, untuk dapat berperan serta dalam mengatasi masalah kesehatan dan anemia gizi besi, serta memperbaiki pola hidup masyarakat. Hal-hal yang dapat diinformasikan antara lain dimulai dari pengertian dan penjelasan singkat mengenai anemia gizi besi, kemudian tanda dan gejala, penyebab serta cara mengatasinya, apa makanan yang dianjurkan dan yang tidak di anjurkan. Dengan adanya peran tenaga kesehatan dalam memberikan pendidikan anemia gizi besi di masyarakat, diharapkan dapat membantu memperbaiki status kesehatannnya, khususnya melalui upaya preventif (pencegahan).

Menurut Proverawati (2011), pengetahuan sangat erat pula kaitannnya dengan terbentuknya sikap. Pengetahuan seseorang tentang suatu obyek mengandung dua aspek yaitu aspek positif dan negatif. Kedua aspek inilah yang akhirnya akan menentukan sikap seseorang terhadap obyek tertentu. Semakain banyak aspek positif dari obyek yang diketahui, akan menumbuhkan sikap makin positif terhadap obyek tersebut. Pengetahuan mempunyai tujuan akhir mengubah sikap dan tindakan ke arah kesadaran untuk melakukan pemenuhan kebutuhan gizi agar tidak terjadi anemia gizi besi.

Hasil penelitian ini juga sejalan dengan Penelitian Weliyati (2010) yang menunjukkan adanya hubungan antara pengetahuan anemia dengan kejadian anemia di SMAN Kota Metro dengan nilai $p=0,001$ dan nilai $O R=0,317$. Hal ini berarti pengetahuan remaja putri yang rendah merupakan protektif terhadap anemia sekitar sepertiga $(0,371)$ dibandingkan yang berpengetahuan baik.

Dengan melihat uraian diatas dan membandingkan dengan teori maka penulis dapat menyimpulkan bahwa kejadian anemia sangat dipengaruhi oleh faktor pengetahuan. Pengetahuan seseorang dapat mempengaruhi terjadinnya anemia. Hal ini karena pengetahuan seseorang akan mempengaruhi perilakunya termasuk pola hidup dan kebiasaan makan. Kurangnya pengetahuan tentang anemia, tandatanda, dampak dan pencegahannya mengakibatkan remaja mengkonsumsi makanan yang kandungan zat besinya sedikit sehingga asupan zat besi yang dibutuhkan remaja putri tidak terpenuhi. Hal ini meningkatkan resiko remaja putri terkena anemia. Untuk itu penanggulangan anemia pada remaja putri hendaknya mulai diprioritaskan sehingga perlu adanya program khusus penaggulangan anemia. Program penanggulangannya bisa berupa penyuluhan pada remaja putri tentang anemia, dampak anemia, pencegahan anemia dan cara penanggulangan anemia, sehingga remaja putri dapat mencegah diri untuk terhindar dari anemia.

\section{SIMPULAN}

Faktor-faktor yang mempengaruhi anemia defesiensi zat besi pada remaja putri di SMK Negeri 1 Terbaggi Besar tahun 2012 adalah, indeks massa tubuh, pengetahuan, asupan suplemen zat besi, dan keadaan menstruasi dengan angka kejadian $(60,8 \%)$.

\section{SARAN}

1. Perlu adanya kerjasama antara tenaga kesehatan dengan dinas pendidikan dalam mensosialisasikan dan memberikan informasi dan pendidikan kesehatan tentang anemia gizi besi serta memasukkan kurikulum tambahan tentang gizi pada remaja, khususnya gizi pada keadaan anemia gizi besi ke sekolah-sekolah, khususnya di SMKN 1 Terbanggi Besar.

2. Bagi Puskesmas hendaknya melakukan pendistribusian tablet tambah darah serta pendeteksian dini anemia gizi besi dengan 
pengukuran kadar haemoglobin secara berkala ke sekolah-sekolah.

3. Dinas kesehatan juga harus melaksanakan supervisi secara teratur untuk melihat dan mengevaluasi pelaksanaan penyuluhan dan sosialisasi anemia gizi besi di masyarakat serta melakukan pembinaan ke semua puskesmas, puskesmas pembantu dan polindes.

\section{DAFTAR PUSTAKA}

Almatsier, Sunita. 2003. Prinsip Dasar Ilmu Gizi. Jakarta: Gramedia Pustaka Utama.

Arisman. 2004. Buku Ajar Ilmu Gizi dalam daur Kehidupan. Jakarta: EGC.

Departemen Gizi dan Kesehatan Masyarakat, FKUI. 2007. Gizi dan Kesehatan Masyarakat. Jakarta: Rajawali Pers.

Depkes RI. 2007. Program Penanggulangan Anemia Gizi Pada Wanita Usia Subur (WUS). Jakrta: Ditjen Gizi Masyarakat.

Farida, Ida. 2006. Determinan kejadian anemia pada remaja putri di kecamatan Gebog Kabupaten kudus tahun Tahun 2006.http:fkesmas.undip.ac.id/(Diakses pada 17 Juni 2010).

Hosmer D.W., and Lemeshow S. 1997. Applied Logistic Regression, A Wiley Interscience Publication. Newyork.

Isniati. 2007. Efek Suplementasi Tablet Fe + Obat Cacing terhadap kadar Hemoglobin Remaja yang Anemia di Pondok Pesantren Tarbiyah IV Angkat Cadung Tahun 2008. http://ffarmasi.unand.ac.id/

(Diakses pada17 Juni 2010).
Notoatmodjo, Soekidjo. 2005. Metodologi Penelitian Kesehatan. Jakarta: Rineka Cipta.

Poltekkes Depkes. 2010. Kesehatan Remaja Problem Dan Solusinya. Jakarta: Salemba Medika.

Proverawati, Atikah. 2011. Anemia dan Anemia Kehamilan. Yogyakarta: Nuha Medika.

Sulaeman. 2006. Hubungan Antara Tingkat Pengetahuan dengan Angka Kejadian Anemia Remaja Putri SMU Negeri 1 Yogyakarta Tahun 2007. http://webcache.gooleuserlontent.com (Diakses pada 11 Mei 2010).

Supariasa, I Dewa Nyoman., Bakri, Bachyar., Fajar, Ibnu. 2002. Penilaian Status Gizi. Jakarta: Penerbit Buku Kedokteran EGC.

Weliyati. 2010. Faktor-faktor yang Berhubungan dengan Kejadian Anemia pada Remaja Putri di SMA Negeri Kota Metro. Jurusan Kebidanan Metro, Poltekkes Tanjungkarang. Lampung.

Winkjosastro, H. 2008. Ilmu Kandungan. Jakarta: Yayasan Bina Pustaka Sarwono Prawirohardjo. 